\title{
Ingestion Pathway Transfer Factors for Plutonium and Americium
}

by

A. Blanchard

Westinghouse Savannah River Company

Savannah River Site

Aiken, South Carolina 29808

J. M. Thompson

WSMS

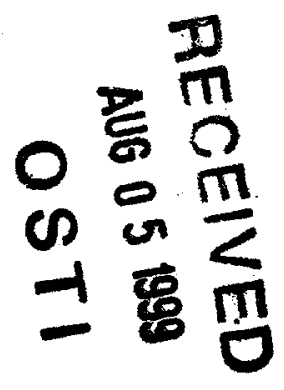

DOE Contract No. DE-AC09-96SR18500

This paper was prepared in connection with work done under the above contract number with the U.S. Department of Energy. By acceptance of this paper, the publisher and/or recipient acknowledges the U.S. Government's right to retain a nonexclusive, royalty-free license in and to any copyright covering this paper, along with the right to reproduce and to authorize others to reproduce all or part of the copyrighted paper. 
Keywords: Ingestion Pathway Emergency Planning Plutonium

Food Contamination

Retention: Lifetime

\section{Ingestion Pathway Transfer Factors for Plutonium and Americium (U)}

January 1999

Classification

\section{UNCLASSIFIED}

DOES NOT CONTAIN

UNCLASSIFIED CONTROLLED

NUCLEAR INFORMATION
ADC \&

Reviewing

Official:

Steven J. Nathan, Prindipal Engineer

Date:

Westinghouse Savannah River Company Project Engineering \& Construction Division Aiken, SC 29808

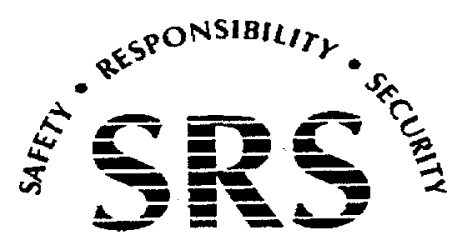

SAVANNAH RIVER SITE

PREPARED FOR THE U.S. DEPARTMENT OF ENERGY UNDER CONTRACT NO. DE-AC09-96SR18500 
Ingestion Pathway Transfer Factors for Plutonium and Americium (U)

Jay M. Thompson

January 1999

Westinghouse Savannah River Company Project Engineering \& Construction Division Aiken, SC 29808

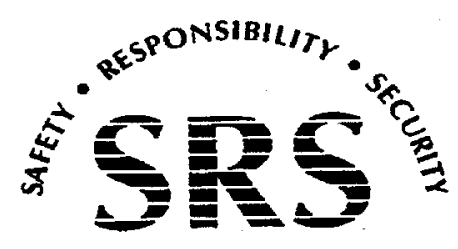

SAVANNAH RIVER SITE.

PREPARED FOR THE U.S. DEPARTMENT OF ENERGY UNDER CONTRACT NO. DE-ACO9-96SR18500 


\section{DISCLAIMER}

This report was prepared as an account of work sponsored by an agency of the United States Government. Neither the United States Government nor any agency thereof, nor any of their employees, makes any warranty, express or implied, or assumes any legal liability or responsibility for the accuracy, completeness, or usefulness of any information, apparatus, product, or process disclosed, or represents that its use would not infringe privately owned rights. Reference herein to any specific commercial product, process, or service by trade name, trademark, manufacturer, or otherwise does not necessarily constitute or imply its endorsement, recommendation, or favoring by the United States Government or any agency thereof. The views and opinions of authors expressed herein do not necessarily state or reflect those of the United States Government or any agency thereof.

This report has been reproduced directly from the best available copy.

Available to DOE and DOE contractors from the Office of Scientific and Technical Information, P.O. Box 62, Oak Ridge, TN 37831; prices available from (615) 576-8401.

Available to the public from the National Technical Information Service, U.S. Department of Commerce, 5285 Port Royal Road, Springfield, VA 22161. 


\section{DISCLAIMER}

Portions of this document may be illegible in electronic image products. Images are produced from the best available original document. 
PROJECT:

DOCUMENT:

TITLE:
N/A

WSRC-TR-99-00005

Ingestion Pathway Transfer Factors for Plutonium and Americium (U)

REVISION NUMBER:

0

AUTHOR/TECHNICAL REVIEWS:

I m Tliompson

J.M. Thompson, Author

E 1 Inomseors

E. A. Thompson, Technical Reviewer
$1 / 13 / 99$ Date $1 / 14 / 99$ Date

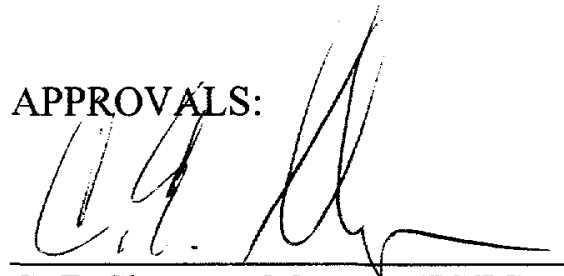

C. E. Shogren, Manager ESTG

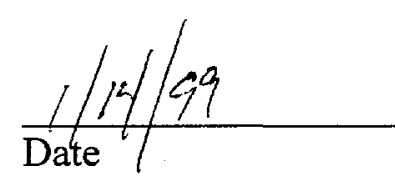




\begin{abstract}
Overall transfer factors for major ingestion pathways are derived for plutonium and americium. These transfer factors relate the radionuclide concentration in a given foodstuff to deposition on the soil. Equations describing basic relationships consistent with Regulatory Guide 1.109 are followed. Updated values and coefficients from IAEA Technical Reports Series No. 364 are used when available. Preference is given to using factors specific to the Savannah River Site.
\end{abstract}




\section{Table of Contents}

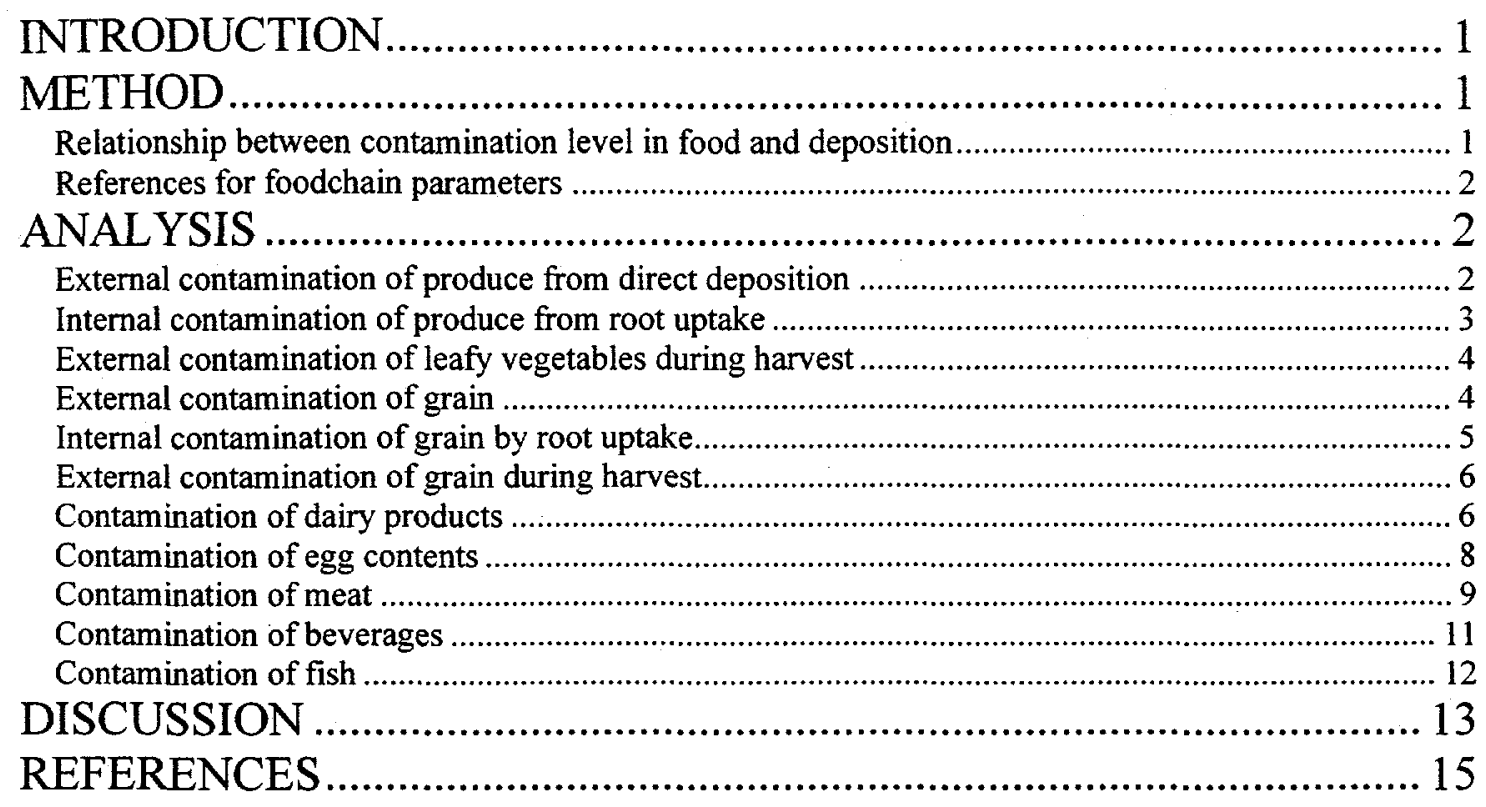




\section{INGESTION PATHWAY TRANSFER FACTORS FOR PLUTONIUM AND AMERICIUM}

\section{INTRODUCTION}

The Manual of Protective Action Guides and Protective Actions for Nuclear Incidents, EPA 400-R-92-001 (EPA 1992), contains guidance and background material from the Food and Drug Administration (FDA), Department of Health and Human Services, concerning protective actions during the intermediate phase to limit ingestion of radionuclides in food and water. These recommendations from the FDA were originally published in the Federal Register in 1982 (FDA 1982).

New FDA guidance, titled "Accidental Contamination of Human Foods and Animal Feeds: Recommendations for State and Local Agencies" (FDA 1998a), supercedes the 1982 recommendations (FDA 1998b). It presents the current approach the FDA will take following a contamination incident. This new guidance incorporates advances in scientific knowledge and changes in radiation protection philosophy since 1982.

To relate concentrations in food (limits set by the new FDA guidance, for example) to deposition of radionuclides (calculated in atmospheric dispersion programs), environmental transfer factors are needed. This paper derives transfer factors, specifically for plutonium and americium, for the pathways listed in FDA 1998a, Table D-2. The transfer factors may be used to derive the relationship between concentrations in food and deposition for any limits, not just the most recent ones from the FDA.

\section{METHOD}

\section{Relationship between contamination level in food and deposition}

The general relationship between the concentration of radionuclide $i$ in a foodstuff $\left({ }_{i} \mathrm{C}_{\text {food }}\right)$ and deposition $\left({ }_{i} \mathrm{D}\right)$ is

${ }_{\mathrm{i}} \mathrm{C}_{\text {food }}={ }_{\mathrm{i}} \mathrm{T} \times{ }_{\mathrm{i}} \mathrm{D}$,

where ${ }_{\mathrm{i}} \mathrm{C}_{\text {food }}$ has units of $\mathrm{Bq}$ per kilogram (wet weight), radionuclide-specific deposition ${ }_{i} \mathrm{D}$ has units of $\mathrm{Bq}$ per square meter, and ${ }_{\mathrm{i}} \mathrm{T}$ is an overall transfer factor in square meters per kilogram. ${ }_{\mathrm{i}} \mathrm{T}$ is often the product of many factors, perhaps encompassing compartments in several trophic levels of the ecosystem.

A small overall transfer factor occurs when a relatively small amount of deposited material reaches the foodstuff of concern. A large transfer factor is associated with radionuclides that transport readily from deposition on the soil to a foodstuff. 


\section{References for foodchain parameters}

The overall transfer factor is often calculated by modeling the sequential movement of radionuclides from deposition on the ground to incorporation in the foodstuff. Parameters may be found in several scientific and regulatory documents. Some parameters are found in Regulatory Guide 1.109, Rev.1 (NRC 1977a). Although RG 1.109 is primarily intended for assessment of routine releases, some values are applicable to acute, accidental releases. An additional source of parameters is HHS Publication FDA 82-8196, Background for Protective Action Recommendations: Accidental Radioactive Contamination of Food and Animal Feeds (Shleien and Chiacchierini 1982). Generic values for parameters have also been published in more recent documents, including Radiological Assessment (Till and Meyer 1983); IAEA Technical Reports Series No. 364, Handbook of Parameter Values for the Prediction of Radionuclide Transfer in Temperate Environments (IAEA 1994); and NCRP 123, Screening Models for Releases of Radionuclides to Atmosphere, Surface Water, and Ground (NCRP 1996). Values specific to the Savannah River Site (SRS) for some parameters may be found in WSRC-RP-91-17, Land and Water Use Characteristics in the Vicinity of the Savannah River Site (Hamby 1991), and an associated Health Physics Journal article, Site-Specific Parameter Values for the Nuclear Regulatory Commission's Food Pathway Dose Model (Hamby 1992).

\section{ANALYSIS}

\section{External contamination of produce from direct deposition}

The relationship between the initial concentration in food ${ }_{i} \mathrm{C}_{\text {produce, direct }}$ from direct deposition of radionuclide $i\left({ }_{i} D\right)$ on produce, following an acute release, is

${ }_{i} C_{\text {produce, direct }}=\left(r / Y_{v}\right) \times{ }_{i} D$

No credit is taken for reduction in radionuclide concentration due to weathering.

The interception fraction $r$ corrects for the difference in total amount of material deposited and that which deposits on edible portions of produce. The agricultural productivity, or yield, $Y_{\mathrm{v}}$ is the wet weight of produce growing per unit area. The SRSspecific yield (wet weight) for leafy vegetables, $Y_{v}$, is given as $0.7 \mathrm{~kg} \mathrm{~m}^{-2}$ per Hamby (1991), Table 2, p. 13. The interception fraction, $r$, is 0.2 for particulates (RG 1.109 p. 1.109-68). These values give an overall transfer factor for this pathway of

${ }_{\mathrm{i}} \mathrm{T}_{\text {produce, direct }}={ }_{\mathrm{i}} \mathrm{C}_{\text {produce, direct }} /{ }_{\mathrm{i}} \mathrm{D}=\mathrm{r} / \mathrm{Y}_{\mathrm{v}}=2.9 \times 10^{-1} \mathrm{~m}^{2} \mathrm{~kg}^{-1}$

This value of the transfer factor is applicable to both plutonium ( $\left.\mathrm{pu} \mathrm{T}_{\text {produce, direct }}\right)$ and americium ( $A m T_{\text {produce, direct). }}$ 


\section{Internal contamination of produce from root uptake}

The soil-to-plant transfer factors, which are expressed as concentration ratios, $\mathrm{CR}_{\text {soil to }}$ plant, dry (Bq per dry weight crop / Bq per dry weight soil) are presented in Table VI of IAEA (1994), pp. 17 to 25 . The category of mixed green vegetables is chosen. Expected

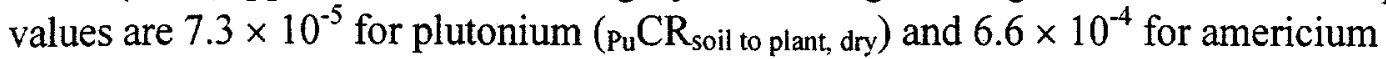
$\left(\mathrm{Am}_{\mathrm{m}} \mathrm{CR}_{\text {soil to plant dry }}\right.$ ). For vegetables, conversion of a concentration ratio based on dry weight to a ratio based on wet weight may be accomplished by dividing the dry weight concentration ratio by a factor of seven (the ratio of wet weight to dry weight), per IAEA (1994), p. 26.

An additional step is necessary to convert soil concentration (activity per unit volume) to deposition on soil (activity per unit area). The concentration ratios in Table VI of IAEA (1994) are based on a soil depth of $0.20 \mathrm{~m}$ for crops and $0.10 \mathrm{~m}$ for pasture, per IAEA (1994), p. 16. A default soil density of $1400 \mathrm{~kg} \mathrm{~m}^{-3}$ is used per IAEA (1994), p. 29. The product of the soil density and soil depth gives the soil areal density. For crops, this is $280 \mathrm{~kg} \mathrm{~m}^{-2}$. For comparison, RG 1.109, p. 1.109-68, recommends a default soil areal concentration value of $240 \mathrm{~kg} \mathrm{~m}^{-2}$, consistent with Till and Meyer (1983), p. 5-29. This factor is the product of the soil density $\left(1600 \mathrm{~kg} \mathrm{~m}^{-3}\right)$ and depth of the root zone $(0.15 \mathrm{~m})$. A value of $280 \mathrm{~kg} \mathrm{~m}^{-2}$ is used in conjunction with the concentration ratios from Table VI of IAEA (1994).

A deposition of ${ }_{\mathrm{Pu}} \mathrm{D} \mathrm{Bq} \mathrm{\textrm {m } ^ { - 2 }}$ of plutonium results in a concentration of $\left(\mathrm{Pu}_{\mathrm{P}} \mathrm{D} / 280\right) \mathrm{Bq} \mathrm{kg}^{-1}$ in the soil of the root zone. The relationship between the deposition and food concentration due to uptake by leafy vegetables of plutonium from the soil is

$$
\begin{aligned}
\mathrm{Pu}_{\mathrm{Pu}} \mathrm{C}_{\text {soil uptake, produce }} & =\left({ }_{\mathrm{Pu}} \mathrm{CR}_{\text {soil to plant, dry }} / 7\right) \times\left(\mathrm{Pu}_{\mathrm{Pu}} \mathrm{D} / 280\right) \\
& =3.7 \times 10^{-8} \mathrm{~m}^{2} \mathrm{~kg}^{-1} \times{ }_{\mathrm{Pu}} \mathrm{D}
\end{aligned}
$$

By rearranging eqn (1) and substituting, it can be shown that the overall transfer factor $\left(\mathrm{Pu}_{\mathrm{T}} \mathrm{T}_{\text {soil uptake, produce }}\right)$ that relates deposition $(\mathrm{Pu} \mathrm{D})$ to the concentration of plutonium in leafy vegetables $\left(\mathrm{Pu}_{\mathrm{su}} \mathrm{C}_{\text {soil uptake, produce }}\right)$ is

${ }_{\mathrm{Pu}} \mathrm{T}_{\text {soil uptake, produce }}={ }_{\mathrm{Pu}} \mathrm{C}_{\text {soil uptake, produce }} / \mathrm{Pu} \mathrm{D}=3.7 \times 10^{-8} \mathrm{~m}^{2} \mathrm{~kg}^{-1}$

Similarly, the relationship between americium deposition and concentration in food due to uptake by leafy vegetables of americium from the soil is

$$
\begin{aligned}
\mathrm{Am}_{\text {soil uptake, produce }} & =\left({ }_{\mathrm{Am}} \mathrm{CR}_{\text {soil to plant, dry }} / 7\right) \times(\mathrm{Am} \mathrm{D} / 280) \\
& =3.4 \times 10^{-7} \mathrm{~m}^{2} \mathrm{~kg}^{-1} \times{ }_{\mathrm{Am}} \mathrm{D} \\
\mathrm{Am}_{\text {soil uptake, produce }} & =3.4 \times 10^{-7} \mathrm{~m}^{2} \mathrm{~kg}^{-1}
\end{aligned}
$$


In this case, there are different overall transfer factors for plutonium and americium, since the soil-to-plant transfer factors ( $\mathrm{Pu}_{\mathrm{C}} \mathrm{CR}_{\text {soil to plant, dry }}$ and ${ }_{\mathrm{Am}} \mathrm{CR}_{\text {soil to plant, dry }}$ ) are different for the two elements.

\section{External contamination of leafy vegetables during harvest}

Resuspension and soil adhesion are processes that result in external contamination of the food product during harvest. It may be significant after weathering has reduced the amount of material deposited initially on the plant to negligible levels. An estimate of external contamination of leafy vegetables is 10 grams of soil per kilogram (dry weight) harvested (IAEA (1994), Table VII, p. 27). Washing or other processing may reduce this amount. It is necessary to express the soil adhesion fraction in terms of wet weight harvested. This adjustment may be made using the wet-to-dry weight ratio of seven. The relationship between the concentration in food and deposition for this pathway, assuming a soil areal density of $280 \mathrm{~kg} \mathrm{~m}^{-2}$, is

${ }_{\mathrm{i}} \mathrm{C}_{\text {adhesion, produce }}=(1 \mathrm{dry} \mathrm{kg} / 7$ wet $\mathrm{kg}) \times\left(10 \mathrm{~g}\right.$ soil $/ 1000 \mathrm{~g}$ dry produce $\times\left({ }_{\mathrm{i}} \mathrm{D} / 280\right)$

${ }_{\mathrm{i}} \mathrm{C}_{\text {adhesion, produce }}=5.1 \times 10^{-6} \mathrm{~m}^{2} \mathrm{~kg}^{-1} \times{ }_{\mathrm{i}} \mathrm{D}$

${ }_{\mathrm{i}} \mathrm{T}_{\text {adhesion, produce }}={ }_{\mathrm{i}} \mathrm{C}_{\text {adhesion, produce }} /{ }_{\mathrm{i}} \mathrm{D}=5.1 \times 10^{-6} \mathrm{~m}^{2} \mathrm{~kg}^{-1}$

The overall transfer factors for this pathway are the same for plutonium and americium.

$\mathrm{Pu}_{\mathrm{Pu}} \mathrm{T}_{\text {adhesion, produce }}={ }_{\mathrm{Am}} \mathrm{T}_{\text {adhesion, produce }}={ }_{\mathrm{i}} \mathrm{T}_{\text {adhesion, produce }}=5.1 \times 10^{-6} \mathrm{~m}^{2} \mathrm{~kg}^{-1}$

Soil adhesion and root uptake represent long-term processes that may affect crops over several growing seasons. In contrast, the direct deposition pathway is significant only for crops present during cloud passage.

\section{External contamination of grain}

The relationship between direct deposition and food contamination ( $\mathrm{Bq} \mathrm{kg}{ }^{-1}$ wet weight) for the consumption of externally contaminated grain may be calculated in a similar manner to that for produce. The crop yield ( $\mathrm{kg}$ wet weight $\mathrm{m}^{-2}$ ) and interception fraction are needed. A crop yield value is not given specifically for grain in RG 1.109 or Hamby (1991). Assuming the yield of grain is the same as produce, the yield, $\mathrm{Y}_{\mathrm{v}}$, is given as 0.7 (wet) $\mathrm{kg} \mathrm{m}^{-2}$ in Hamby (1991), Table 2, p. 13. The interception fraction, $\mathrm{r}$, is 0.2 for particulates (RG 1.109, p. 1.109-68).

The relationship between the concentration in food and deposition for direct deposition on grain is

$$
\begin{aligned}
\mathrm{C}_{\text {grain, direct }} & =\left(\mathrm{r} / \mathrm{Y}_{\mathrm{v}}\right) \times{ }_{\mathrm{i}} \mathrm{D} \\
& =2.9 \times 10^{-1} \mathrm{~m}^{2} \mathrm{~kg}^{-1} \times{ }_{\mathrm{i}} \mathrm{D}
\end{aligned}
$$


${ }_{\mathrm{i}} \mathrm{T}_{\text {grain, direct }}={ }_{\mathrm{i}} \mathrm{C}_{\text {grain, direct }} /{ }_{\mathrm{i}} \mathrm{D}=2.9 \times 10^{-1} \mathrm{~m}^{2} \mathrm{~kg}^{-1}$

The overall transfer factors for this pathway are the same for plutonium and americium.

${ }_{\mathrm{Pu}} T_{\text {grain, direct }}={ }_{\mathrm{Am}} \mathrm{T}_{\text {grain, direct }}={ }_{\mathrm{i}} \mathrm{T}_{\text {grain, direct }}=2.9 \times 10^{-1} \mathrm{~m}^{2} \mathrm{~kg}^{-1}$

This value is the same as for leafy vegetables since interception fractions and yields are the same. The value for the overall transfer factor $\left(\mathrm{T}_{\text {grain, direct }}\right)$ is probably very conservative (high) since the edible parts of cereals are often less exposed than the edible parts of leafy vegetables.

\section{Internal contamination of grain by root uptake}

The soil-to-plant transfer factors ; $\mathrm{CR}_{\text {soil to plant, dry }}(\mathrm{Bq}$ per dry weight crop / $\mathrm{Bq}$ per dry weight soil) are presented in Table VI of IAEA (1994), pp. 17 to 25 . The category "cereals" is chosen for grain. Expected values are $8.6 \times 10^{-6}$ for plutonium $\left(\mathrm{Pu}_{\mathrm{CR}} \mathrm{R}_{\text {soil to plant, }}\right.$ $\mathrm{dry})$ and $2.2 \times 10^{-5}$ for americium $\left(\mathrm{Am}_{\mathrm{Am}} \mathrm{CR}_{\text {soil to plant, dry }}\right)$. Dry weight contents of cereals are presented in Table V, p. 15, of IAEA (1994). The average dry weight content of cereals is about $86 \%$. This value is consistent with the grains class average in Table 5.16, p. 548, of Till and Meyer (1983). Each dry weight-based transfer factor must be multiplied by the dry weight content, since concentrations in food calculated here are based on wet food weight.

An areal concentration value of $280 \mathrm{~kg} \mathrm{~m}^{-2}$ is assumed.

The relationship between deposition and the concentration in grain due to root uptake of plutonium from the soil is

$$
\begin{aligned}
& \mathrm{Pu}_{\mathrm{Pu}} \mathrm{C}_{\text {soil uptake, grain }}=\left(\mathrm{P}_{\mathrm{Pu}} \mathrm{CR}_{\text {soil to plant, dry }} \times 0.86\right) \times\left(\mathrm{Pu}_{\mathrm{U}} \mathrm{D} / 280\right) \\
& \quad=2.6 \times 10^{-8} \mathrm{~m}^{2} \mathrm{~kg}^{-1} \times \mathrm{Pu} \mathrm{D} \\
& \mathrm{Pu}_{\text {soil uptake, grain }}={ }_{\mathrm{Pu}} \mathrm{C}_{\text {soil uptake, grain }} / \mathrm{Pu} \mathrm{D}=2.6 \times 10^{-8} \mathrm{~m}^{2} \mathrm{~kg}^{-1}
\end{aligned}
$$

Similarly, the relationship between deposition and the concentration in grain due to root uptake of americium from the soil is

$$
\begin{aligned}
& { }_{\mathrm{Am}} \mathrm{C}_{\text {soil uptake, grain }}=\left({ }_{\mathrm{Am}} \mathrm{CR}_{\text {soil to plant, dry }} \times 0.86\right) \times\left({ }_{\mathrm{Am}} \mathrm{D} / 280\right) \\
& { }_{\mathrm{Am}} \mathrm{T}_{\text {soil uptake, grain }}={ }_{\mathrm{Am}} \mathrm{C}_{\text {soil uptake, grain }} /{ }_{\mathrm{Am}} \mathrm{D}=6.8 \times 10^{-8} \mathrm{~m}^{2} \mathrm{~kg}^{-1}
\end{aligned}
$$




\section{External contamination of grain during harvest}

Resuspension and soil adhesion are processes that result in external contamination of the food product during harvest. It may be significant after weathering has reduced the amount of material deposited initially on the plant to negligible levels. An estimate of external contamination of grain is 4 grams of soil per kilogram (dry weight) harvested (IAEA (1994) Table VII, p. 27). Washing or other processing may reduce this amount. It is necessary to express the soil adhesion fraction in terms of wet weight harvested. This adjustment may be made using the dry weight content of 0.86 dry weight/wet weight. The relationship between the concentration in food and deposition for this pathway, assuming a soil areal density of $280 \mathrm{~kg} \mathrm{~m}^{-2}$, is

$$
\begin{aligned}
{ }_{\mathrm{i}} \mathrm{C}_{\text {adhesion, grain }} & =[(0.86 \mathrm{dry} / \text { wet })(4 \mathrm{~g} \text { soil } / 1000 \mathrm{~g} \text { dry grain })] \times{ }_{\mathrm{i}} \mathrm{D} / 280 \mathrm{~kg} \mathrm{~m}^{-2} \\
& =1.2 \times 10^{-5} \mathrm{~m}^{2} \mathrm{~kg}^{-1} \times{ }_{\mathrm{i}} \mathrm{D} \\
{ }_{\mathrm{i}} \mathrm{T}_{\text {adhesion, grain }} & ={ }_{\mathrm{i}} \mathrm{C}_{\text {adhesion, grain }} / \mathrm{i}=1.2 \times 10^{-5} \mathrm{~m}^{2} \mathrm{~kg}^{-1}
\end{aligned}
$$

Since the factors for americium and plutonium are the same,

$$
{ }_{\mathrm{Pu}} \mathrm{T}_{\text {adhesion, grain }}={ }_{\mathrm{Am}} \mathrm{T}_{\text {adhesion, grain }}={ }_{\mathrm{i}} \mathrm{T}_{\text {adhesion, grain }}=1.2 \times 10^{-5} \mathrm{~m}^{2} \mathrm{~kg}^{-1}
$$

\section{Contamination of dairy products}

The milk pathway is assumed to characterize pathways for all dairy products.

The milk pathway is described by a two-step process. Deposition contaminates forage, then the forage is consumed by cows and contaminated milk is produced. The amount of external contamination on forage due to direct deposition of radionuclide $i$ is

${ }_{i} C_{\text {forage, direct }}=\left(\mathrm{r} / \mathrm{Y}_{\mathrm{v}}\right) \times{ }_{\mathrm{i}} \mathrm{D}$

The fraction of deposition initially retained on pasture grass, $r$, is 0.2 for chronic releases (RG 1.109, p. 1.109-68). A deposition fraction of 0.5 is given on page 13 of Shleien and Chiacchierini (1982), and is adopted as the value for pasture following an acute release of particulates in the following calculation. The SRS-specific agricultural productivity per unit area (measured in wet weight) $\left(Y_{v}\right)$ for the grass-cow-milk pathway is $1.8 \mathrm{~kg} \mathrm{~m}^{-2}$ (Hamby 1991). This is somewhat greater than the generic value for agricultural productivity for this pathway of $0.7 \mathrm{~kg} \mathrm{~m}^{-2}$ (RG $\left.1.109, \mathrm{p} .1 .109-69\right)$. The SRS-specific value is used in the following calculations. Deposition $\left({ }_{i} D\right)$ may be either plutonium or americium, depending on which radionuclide is of interest.

Equation (C-10) of RG 1.109, p. 1.109-27, provides a means to estimate the radionuclide concentration in milk $\left({ }_{i} \mathrm{C}^{\mathrm{m}}\right)$ if the contamination level of feed is known:

${ }_{\mathrm{i}} \mathrm{C}^{\mathrm{m}}={ }_{\mathrm{i}} \mathrm{F}^{\mathrm{m}} \times{ }_{\mathrm{i}} \mathrm{C}^{\mathrm{v}} \times \mathrm{Q}_{\mathrm{F}} \times \exp \left(-\lambda_{\mathrm{i}} \times \mathrm{t}_{\mathrm{f}}\right)$ 
This equation is for chronic intake by the cow and represents an upper bound to the acute case if deposition levels immediately after the accident are used to calculate contamination on forage. Contamination levels would be expected to decrease over time due to weathering, resulting in lower concentrations of radionuclides in milk.

${ }_{\mathrm{i}} \mathrm{F}^{\mathrm{m}}$ is the average fraction of a cow's daily intake of radionuclide $\mathrm{i}$ that appears in each liter of milk. $\mathrm{F}^{\mathrm{m}}$ has units of $\mathrm{Bq} \mathrm{L}^{-1}$ of milk per $\mathrm{Bq}$ day ${ }^{-1}$ consumed by the cow, or $\mathrm{d} \mathrm{L}^{-1}$. ${ }_{\mathrm{i}} \mathrm{F}^{\mathrm{m}}$ for plutonium is $1.1 \times 10^{-6} \mathrm{~d} \mathrm{~L}^{-1}$, and for americium is $1.5 \times 10^{-6} \mathrm{~d} \mathrm{~L}^{-1}$ (IAEA (1994), Table XII, p. 35).

${ }_{\mathrm{i}} \mathrm{C}^{\mathrm{v}}$ is the concentration of radionuclide $\mathrm{i}$ in the cow's feed, with units of $\mathrm{Bq} \mathrm{kg}^{-1}$ (wet weight). Feed may be either pasture grass (contaminated forage) or stored feed (assumed uncontaminated). ${ }_{i} C^{\mathrm{V}}$ is set equal to ${ }_{i} \mathrm{C}_{\text {forage, direct }}$ for contaminated forage.

$\mathrm{Q}_{\mathrm{F}}$ is the amount of contaminated feed consumed by the cow per day. It should be expressed in terms of wet weight, since the contamination level of forage is also in wet weight. The total consumption rate (wet weight per day) of forage consumed by a dairy cow is $52 \mathrm{~kg} \mathrm{~d}^{-1}$ (Hamby 1991). The SRS-specific fraction of intake from pasture is 0.56 (Hamby 1991). The product of these factors results in a daily consumption rate of contaminated forage $\left(\mathrm{Q}_{\mathrm{F}}\right)$ of $29.12 \mathrm{~kg} \mathrm{~d}^{-1}$.

The exponential factor is the product of the decay constant for radionuclide $i$ and the time to market $\left(t_{s}\right)$. The decay constants for plutonium and americium isotopes of concern are very small. Time to market is usually taken as 2 days (RG 1.109 , p. 1.109-27). The product of the decay constant and time to market is about 0 , resulting in the exponential term having a value of about one. For long-lived radionuclides, the exponential term can be set equal to unity. The simplified equation is now

$$
{ }_{i} \mathrm{C}^{\mathrm{m}}={ }_{\mathrm{i}} \mathrm{F}^{\mathrm{m}} \times{ }_{\mathrm{i}} \mathrm{C}_{\text {forage, direct }} \times \mathrm{Q}_{\mathrm{F}}
$$

Substituting in the expression for ${ }_{i} \mathrm{C}_{\text {forage, direct }}$ from eqn (27) into eqn (29) gives

$$
{ }_{i} C^{m}={ }_{j} F^{m} \times\left(r / Y_{v}\right) \times{ }_{i} D \times Q_{F}
$$

The overall transfer factor ${ }_{\mathrm{i}} \mathrm{T}^{\mathrm{m}}$ for the milk pathway from direct deposition of the ith radionuclide is therefore

$$
{ }_{\mathrm{i}} \mathrm{T}^{\mathrm{m}}={ }_{\mathrm{i}} \mathrm{C}^{\mathrm{m}} /{ }_{\mathrm{i}} \mathrm{D}={ }_{\mathrm{i}} \mathrm{F}^{\mathrm{m}} \times\left(\mathrm{r} / \mathrm{Y}_{\mathrm{v}}\right) \times \mathrm{Q}_{\mathrm{F}}
$$

For plutonium,

$$
\begin{aligned}
& { }_{{ }_{\mathrm{Pu}}} \mathrm{T}^{\mathrm{m}}={ }_{\mathrm{Pu}} F^{\mathrm{m}} \times\left(\mathrm{r} / \mathrm{Y}_{\mathrm{v}}\right) \times \mathrm{Q}_{\mathrm{F}} \\
& =1.1 \times 10^{-6} \mathrm{~d} \mathrm{~L}^{-1} \times\left(0.5 / 1.8 \mathrm{~kg} \mathrm{~m}^{-2}\right) \times 29.12 \mathrm{~kg} \mathrm{~d}^{-1}
\end{aligned}
$$




$$
=8.9 \times 10^{-6} \mathrm{~m}^{2} \mathrm{~L}^{-1}=8.9 \times 10^{-6} \mathrm{~m}^{2} \mathrm{~kg}^{-1}
$$

Since milk has a density of $1 \mathrm{~kg} \mathrm{~L}^{-1}$, the overall transfer factor is numerically equivalent when expressed in units of $\mathrm{m}^{2} \mathrm{~L}^{-1}$ or $\mathrm{m}^{2} \mathrm{~kg}^{-1}$.

Similarly, for americium,

$$
\begin{aligned}
{ }_{A m} T^{m} & ={ }_{A m} F^{m} \times\left(r / Y_{v}\right) \times Q_{F} \\
& =1.5 \times 10^{-6} \mathrm{~d} \mathrm{~L}^{-1} \times\left(0.5 / 1.8 \mathrm{~kg} \mathrm{~m}^{-2}\right) \times 29.12 \mathrm{~kg} \mathrm{~d}^{-1} \\
& =1.2 \times 10^{-5} \mathrm{~m}^{2} \mathrm{~L}^{-1}=1.2 \times 10^{-5} \mathrm{~m}^{2} \mathrm{~kg}^{-1}
\end{aligned}
$$

\section{Contamination of egg contents}

The relationship between the concentration of long-lived radionuclide $i$ in egg contents in $\mathrm{Bq} \mathrm{kg}^{-1}\left({ }_{\mathrm{i}} \mathrm{C}^{\mathrm{e}}\right)$ and the amount of contaminated feed consumed per day is similar to the relationship for contaminated forage and level of radionuclides in milk

$$
{ }_{i} \mathrm{C}^{\mathrm{e}}={ }_{\mathrm{i}} \mathrm{F}^{\mathrm{e}} \times{ }_{\mathrm{i}} \mathrm{C}^{\mathrm{v}} \times \mathrm{Q}_{\mathrm{F}}
$$

${ }_{i} \mathrm{~F}^{\mathrm{e}}$ is the average fraction of a laying hen's daily intake of radionuclide $i$ that appears in each kilogram of egg contents. $\mathrm{F}^{\mathrm{e}}$ has units of $\mathrm{Bq} \mathrm{kg}^{-1}$ of egg contents per $\mathrm{Bq}$ day ${ }^{-1}$ consumed by the laying hen, or $\mathrm{dg}^{-1} . \mathrm{Pu}^{\mathrm{e}}$ is $5 \times 10^{-4} \mathrm{~d} \mathrm{~kg}^{-1}$, and $\mathrm{Am}^{\mathrm{e}}$ is $4 \times 10^{-3} \mathrm{~d} \mathrm{~kg}^{-1}$ (IAEA (1994), Table XX, p. 41).

${ }_{\mathrm{i}} \mathrm{C}^{\mathrm{v}}$ is the concentration of radionuclide $\mathrm{i}$ in the laying hen's feed, with units of $\mathrm{Bq} \mathrm{kg}{ }^{-1}$ (wet weight). The typical feedstuffs are cereals and protein feed (IAEA (1994), Table X, p. 32). If the entire diet is assumed to consist of grain contaminated by fresh deposition, the parameters from the section on externally contaminated grain may be used. The conservative assumption is made that all of the laying hens' feed is from contaminated grain. ${ }_{i} \mathrm{C}^{\mathrm{v}}$ is set equal to ${ }_{i} \mathrm{C}_{\text {grain, direct. }}$

The concentration of radionuclide i resulting from direct deposition onto grain is

$$
{ }_{i} C_{\text {grain, direct }}=\left(r / Y_{v}\right) \times{ }_{i} D
$$

$\mathrm{Q}_{\mathrm{F}}$ is the amount of feed consumed by the hen per day. It should be expressed in terms of wet weight, since the contamination level of grain is also in wet weight. Laying hens have a consumption rate of dry matter of $0.1 \mathrm{~kg} \mathrm{~d}^{-1}$ (IAEA (1994) Table XI, p. 33). Dry weight contents of cereals (assumed to be representative of grain) are presented in IAEA (1994), Table V, p. 15. The average dry weight content of cereals is about $86 \%$, so the wet consumption rate is $\left(0.1 \mathrm{~kg} \mathrm{~d}^{-1} / 0.86\right)=0.116 \mathrm{~kg} \mathrm{~d}^{-1}$. 
The relationship between the concentration in eggs and deposition may be estimated by combining eqn (38) and eqn (39).

$$
\begin{aligned}
{ }_{i} C^{e} & ={ }_{i} F^{e} \times{ }_{i} C_{\text {grain, direct }} \times Q_{F} \\
& ={ }_{i} F^{e} \times r / Y_{v} \times{ }_{i} D \times Q_{F}
\end{aligned}
$$

The overall transfer factor for nuclide $i$ is

${ }_{i} T^{e}={ }_{i} C^{e} / D_{i}={ }_{i} F^{e} \times\left(r / Y_{v}\right) \times Q_{F}$

A yield (wet) of $0.7 \mathrm{~kg} \mathrm{~m}^{-2}$ and an interception fraction $\mathrm{r}$ of 0.2 are assumed.

For plutonium,

$$
\begin{aligned}
\mathrm{Pu}_{\mathrm{T}} \mathrm{T}^{\mathrm{e}} & ={ }_{\mathrm{Pu}} \mathrm{F}^{\mathrm{e}} \times\left(\mathrm{r} / \mathrm{Y}_{\mathrm{v}}\right) \times \mathrm{Q}_{\mathrm{F}} \\
& =5 \times 10^{-4} \mathrm{~d} \mathrm{~kg}^{-1} \times\left(0.2 / 0.7 \mathrm{~kg} \mathrm{~m}^{-2}\right) \times 0.116 \mathrm{~kg} \mathrm{~d}^{-1} \\
& =1.7 \times 10^{-5} \mathrm{~m}^{2} \mathrm{~kg}^{-1}
\end{aligned}
$$

Similarly, for americium,

$$
\begin{aligned}
{ }_{A m} T^{e} & ={ }_{A m} F^{e} \times\left(r / Y_{v}\right) \times Q_{F} \\
& =4 \times 10^{-3} \mathrm{~d} \mathrm{~kg}^{-1} \times\left(0.2 / 0.7 \mathrm{~kg} \mathrm{~m}^{-2}\right) \times 0.116 \mathrm{~kg} \mathrm{~d}^{-1} \\
& =1.3 \times 10^{-4} \mathrm{~m}^{2} \mathrm{~kg}^{-1}
\end{aligned}
$$

\section{Contamination of meat}

The concentration of radionuclides in meat $\left(\mathrm{C}^{\mathrm{F}}\right)$ is dependent on the consumption rate of forage by the animal and the contamination level of the forage. Equation (C-12) of RG 1.109 , p. $1.109-28$, is

${ }_{\mathrm{i}} \mathrm{C}^{\mathrm{F}}={ }_{\mathrm{i}} \mathrm{F}^{\mathrm{f}} \times{ }_{\mathrm{i}} \mathrm{C}^{\mathrm{v}} \times \mathrm{Q}_{\mathrm{F}} \times \exp \left(-\lambda_{\mathrm{i}} \times \mathrm{t}_{\mathrm{s}}\right)$

As in the analysis for the milk pathway, the exponential term may be set equal to unity for long-lived radionuclides ( $t_{s}$, the time to slaughter, is 20 days; $\lambda_{i}$ is very close to zero for long-lived radionuclides; the product of the two terms is essentially zero). The simplified equation is

${ }_{\mathrm{i}} \mathrm{C}^{\mathrm{F}}={ }_{\mathrm{i}} \mathrm{F}^{\mathrm{f}} \times{ }_{\mathrm{i}} \mathrm{C}^{\mathrm{v}} \times \mathrm{Q}_{\mathrm{F}}$

${ }_{i} \mathrm{~F}^{\mathrm{f}}$ is the fraction of daily intake by the animal of radionuclide $i \mathrm{that}$ appears in the edible flesh. It has units of $\mathrm{Bq} \mathrm{kg}^{-1}$ of meat per $\mathrm{Bq} \mathrm{d} \mathrm{d}^{-1}$ consumed by the animal, or $\mathrm{dg}^{-1}$. It 
varies by radionuclide and animal. Expected values from IAEA (1994), Tables XV to XVIII, pp. 37-39, are presented in Table 1.

$\mathrm{Q}_{\mathrm{F}}$ is the amount of contaminated forage consumed by the animal per day. It should be expressed in terms of wet weight, since the contamination level of forage is also in wet weight. The site-specific total wet forage consumption rate for beef is $36 \mathrm{~kg} \mathrm{~d}^{-1}$ (Hamby 1991). As with the milk pathway, the total forage consumption rate is assumed to consist of contaminated pasture grass and uncontaminated other feed. The SRS-specific value for the fraction of intake from pasture for beef is 0.75 (Hamby 1991). The product of the total consumption rate and the fraction of intake from pasture gives a contaminated forage consumption rate of $27 \mathrm{~kg} \mathrm{~d}^{-1}$, and is presented in Table 1. The quantities (dry weight) of forage consumed by other animals are also presented in Table 1, and are values from IAEA (1994), Table XI, p. 33. Wet forage consumption rates are 4.5 times the dry consumption rates per Table 5.16, p. 5-48 of Till and Meyer (1983). For meat pathways other than beef, all forage consumed by the animal is assumed to be contaminated.

Table 1: Intake-to-meat transfer factors and forage consumption rates

\begin{tabular}{ccccc}
\hline Meat & $\mathrm{PuF}^{\mathrm{f}}, \mathrm{d} \mathrm{kg}^{-1}$ & $\mathrm{Am}^{\mathrm{f}}, \mathrm{d} \mathrm{kg}^{-1}$ & $\begin{array}{c}\text { Contaminated } \\
\text { forage } \\
\text { consumption rate, } \\
\text { dry kg d }\end{array}$ & $\begin{array}{c}\text { Contaminated } \\
\text { forage } \\
\text { consumption rate, } \\
\text { wet kg d }\end{array}$ \\
\hline Beef & $1 \times 10^{-5}$ & $4 \times 10^{-5}$ & - & 27 \\
Veal & $1 \times 10^{-3}$ & $1 \times 10^{-3}$ & 1.9 & 8.6 \\
Sheep & $9.4 \times 10^{-5}$ & $2.0 \times 10^{-4}$ & 1.3 & 5.9 \\
Lamb & $3.1 \times 10^{-3}$ & $4.1 \times 10^{-3}$ & 1.1 & 5.0 \\
Pork & $8.0 \times 10^{-5}$ & $1.7 \times 10^{-4}$ & 2.4 & 11 \\
Poultry & $3 \times 10^{-3}$ & $6 \times 10^{-3}$ & 0.07 & 0.32 \\
\hline
\end{tabular}

${ }_{\mathrm{i}} \mathrm{C}^{\mathrm{v}}$ is the concentration of radionuclide $\mathrm{i}$ in the animal's feed, with units of $\mathrm{Bq} \mathrm{kg}^{-1}$ (wet weight). Feed is assumed to be forage contaminated by direct deposition. The equation relating concentration of radionuclide $\mathrm{i}$ in forage $\left({ }_{i} \mathrm{C}_{\text {forage, direct }}\right)$ to the amount of radionuclide i deposited on the ground $(\mathrm{i} D)$ is

${ }_{i} C^{v}={ }_{i} C_{\text {forage, direct }}=\left(r / Y_{v}\right) \times{ }_{i} D$

Substituting the expression for ${ }_{i} C_{\text {forage, direct }}$ in eqn (51) for ${ }_{i} C^{v}$ in eqn (50) gives

${ }_{i} C^{F}={ }_{i} F^{f} \times\left(r / Y_{v}\right) \times{ }_{i} D \times Q_{F}$

The overall transfer factors for the meat pathways are

${ }_{i} T^{F}={ }_{i} C^{F} /{ }_{i} D={ }_{i} F^{f} \times\left(r / Y_{v}\right) \times Q_{F}$ 
The agricultural production rate $Y_{v}$ is measured in wet weight. An SRS-specific value of $1.8 \mathrm{~kg} \mathrm{~m}^{-2}$ (wet weight of pasture grass per unit area) is chosen for meat calculations (Hamby 1991). An interception fraction $r$ for pasture of 0.5 is assumed as in the dairy pathway calculation. Deposition $\left({ }_{i} \mathrm{D}\right)$ may be either plutonium or americium, depending on which radionuclide is of interest. Table 2 lists overall transfer factors for six meat pathways, for plutonium and americium.

Table 2: Meat overall transfer factors

\begin{tabular}{ccc}
\hline $\begin{array}{c}\text { Meat } \\
\text { pathway }\end{array}$ & $\begin{array}{c}\mathrm{Pu}^{2} \mathrm{~T}^{\mathrm{F}} \\
\mathrm{m}^{2} \mathrm{~kg}\end{array}$ & $\begin{array}{c}\mathrm{Am}^{2} \mathrm{~T}^{\mathrm{F}} \\
\mathrm{m}^{2} \mathrm{~kg}\end{array}$ \\
\hline Beef & $7.5 \times 10^{-5}$ & $3.0 \times 10^{-4}$ \\
Veal & $2.4 \times 10^{-3}$ & $2.4 \times 10^{-3}$ \\
Sheep & $1.5 \times 10^{-4}$ & $3.3 \times 10^{-4}$ \\
Lamb & $4.3 \times 10^{-3}$ & $5.6 \times 10^{-3}$ \\
Pork & $2.4 \times 10^{-4}$ & $5.1 \times 10^{-4}$ \\
Poultry & $2.6 \times 10^{-4}$ & $5.3 \times 10^{-4}$ \\
\hline
\end{tabular}

The transfer factors in Table 2 consider only the intake from direct deposition, and do not account for added intake from soil adhesion. Additional discussion is on p. 33 of IAEA (1994).

\section{Contamination of beverages}

Drinking water is assumed to be representative of the beverage pathway.

The concentration in water is conservatively calculated by diluting instantaneously deposited activity throughout the depth of water. For insoluble contaminants, this will usually be a very conservative assumption, since particulates are expected to settle into the sediments. For a water depth (d) of 1.0 meter and density $\rho_{\mathrm{w}}$ of $1.0 \times 10^{3} \mathrm{~kg} \mathrm{~m}^{-3}$, the activity of radionuclide $i$ per unit mass of water $\left({ }_{i} C_{w}\right)$ from a deposition $\left({ }_{i} D\right)$ is

${ }_{\mathrm{j}} \mathrm{C}_{\mathrm{w}}={ }_{\mathrm{i}} \mathrm{D} /\left(\rho_{\mathrm{w}} \times \mathrm{d}\right)$

${ }_{i} \mathrm{C}_{\mathrm{w}}={ }_{\mathrm{i}} \mathrm{D} /\left(1.0 \times 10^{3} \mathrm{~kg} \mathrm{~m}^{-3} \times 1.0 \mathrm{~m}\right)$

Where ${ }_{i} C_{w}$ is in $B q k^{-1}$ and ${ }_{i} \mathrm{D}$ is in $\mathrm{Bq} \mathrm{m}{ }^{-2}$. The transfer factor relating concentration in water $\left({ }_{i} C_{w}\right)$ to deposition $\left({ }_{i} D\right)$ is

$$
\begin{aligned}
\mathrm{i}_{\text {i }} \mathrm{T}_{\text {water }} & ={ }_{\mathrm{i}} \mathrm{C}_{\mathrm{w}} /{ }_{\mathrm{i}} \mathrm{D}=\rho_{\mathrm{w}} \times \mathrm{d} \\
& =1.0 \times 10^{-3} \mathrm{~m}^{2} \mathrm{~kg}^{-1} .
\end{aligned}
$$


Since the factors for americium and plutonium are the same,

${ }_{\mathrm{Pu}} \mathrm{T}_{\text {water }}={ }_{\mathrm{Am}} \mathrm{T}_{\text {water }}={ }_{\mathrm{i}} \mathrm{T}_{\text {water }}=1.0 \times 10^{-3} \mathrm{~m}^{2} \mathrm{~kg}^{-1}$

The value $1.0 \times 10^{-3} \mathrm{~m}^{2} \mathrm{~kg}^{-1}$ should be considered a conservative upper bound on the overall transfer factor for drinking water. Sedimentation and other processes will reduce the activity in water. If deposition occurs on flowing bodies of water, the period of exposure will be small.

\section{Contamination of fish}

Acute uptake in fish will be bounded by the chronic uptake. Given ${ }_{\mathrm{i}} \mathrm{C}_{\mathrm{w}}$ from the calculation for drinking water, the concentration in fish is

${ }_{\mathrm{i}} \mathrm{C}_{\text {fish }}=\mathrm{B}_{\mathrm{p} i \mathrm{i}} \mathrm{C}_{\mathrm{w}}$

Where $B_{p}$ is a concentration factor for edible portions of fish with an expectation value of $30\left(\mathrm{~Bq} \mathrm{~kg}^{-1}\right.$ wet weight per $\mathrm{Bq} \mathrm{L}$ of water) for both plutonium and americium (IAEA (1994), Table XXII, p. 45). Concentration factors of 30 are also given in NCRP (1996), Table 6.1, for plutonium and americium. The relationship between deposition and water concentration is given in eqn (55). Combining eqn (55) and eqn (59) gives

${ }_{\mathrm{i}} \mathrm{C}_{\text {fish }}=\mathrm{B}_{\mathrm{p}} \mathrm{C}_{\mathrm{w}}=\mathrm{B}_{\mathrm{p}} \times{ }_{\mathrm{i}} \mathrm{D} /\left(1.0 \times 10^{3} \mathrm{~kg} \mathrm{~m}^{-3} \times 1.0 \mathrm{~m}\right)$

The overall transfer factor is

$$
\begin{aligned}
{ }_{i} \mathrm{~T}_{\text {fish }} & ={ }_{i} \mathrm{C}_{\text {fish }} /{ }_{\mathrm{i}} \mathrm{D}=\mathrm{B}_{\mathrm{p}} /\left(1.0 \times 10^{3} \mathrm{~kg} \mathrm{~m}^{-3} \times 1.0 \mathrm{~m}\right) \\
& =30 /\left(1.0 \times 10^{3} \mathrm{~kg} \mathrm{~m}^{-2}\right) \\
& =3.0 \times 10^{-2} \mathrm{~m}^{2} \mathrm{~kg}^{-1} \text { for both plutonium and americium. }
\end{aligned}
$$

Due to the insoluble nature of most transuranic compounds, this value is probably too high by a factor of at least ten. A typical rule of thumb is that only a few percent of the deposited plutonium is available in the water; the rest is bound in the sediments. Additionally, it takes time for concentrations of radionuclides in fish to come to equilibrium. This calculation assumes fish are continuously exposed to the initial level of deposited radionuclides in water. This would occur only in stagnant bodies of water, with no settling of radionuclides into sediment. In flowing bodies of water (such as the Savannah River), waterborne concentration at a particular location would decrease rapidly over time after the initial deposition, and concentrations of radionuclides in fish would be expected to be much lower than for fish chronically exposed in stagnant bodies of water. 


\section{DISCUSSION}

Tables 3 and 4 summarize overall transfer factors for plutonium and americium, respectively.

Table 3: Overall transfer factors for plutonium

\begin{tabular}{lc}
\hline $\begin{array}{l}\text { Dietary Component from } \\
\text { FDA (1998a), Table D-2 }\end{array}$ & $\begin{array}{c}\text { Plutonium overall transfer factors } \\
\mathrm{T}, \mathrm{m}^{2} \mathrm{~kg}^{-1}\end{array}$ \\
\hline Dairy & $8.9 \times 10^{-6}$ \\
Egg contents & $1.7 \times 10^{-5}$ \\
Meat $\quad$ Beef & $7.5 \times 10^{-5}$ \\
$\quad$ Veal & $2.4 \times 10^{-3}$ \\
$\quad$ Sheep & $1.5 \times 10^{-4}$ \\
$\quad$ Lamb & $4.3 \times 10^{-3}$ \\
$\quad$ Pork & $2.4 \times 10^{-4}$ \\
$\quad$ Poultry & $2.6 \times 10^{-4}$ \\
Fish $\quad 3.0 \times 10^{-2}$ \\
Produce - direct deposition & $2.9 \times 10^{-1}$ \\
Produce - root uptake & $3.7 \times 10^{-8}$ \\
Produce - soil adhesion & $5.1 \times 10^{-6}$ \\
Grain - direct deposition & $2.9 \times 10^{-1}$ \\
Grain - root uptake & $2.6 \times 10^{-8}$ \\
Grain - soil adhesion & $1.2 \times 10^{-5}$ \\
Beverage & $1.0 \times 10^{-3}$ \\
\hline
\end{tabular}


Table 4: Overall transfer factors for americium

\begin{tabular}{ll}
\hline $\begin{array}{l}\text { Dietary Component from } \\
\text { FDA (1998a), Table D-2 }\end{array}$ & $\begin{array}{c}\text { Americium overall transfer factors } \\
\text { T, } \mathrm{m}^{2} \mathrm{~kg}^{-1}\end{array}$ \\
\hline Dairy & $1.2 \times 10^{-5}$ \\
Egg contents & $1.3 \times 10^{-4}$ \\
Meat & \\
$\quad$ Beef & $3.0 \times 10^{-4}$ \\
$\quad$ Veal & $2.4 \times 10^{-3}$ \\
$\quad$ Sheep & $3.3 \times 10^{-4}$ \\
$\quad$ Lamb & $5.6 \times 10^{-3}$ \\
$\quad$ Pork & $5.1 \times 10^{-4}$ \\
$\quad$ Poultry & $5.3 \times 10^{-4}$ \\
Fish $\quad 3.0 \times 10^{-2}$ \\
Produce-direct deposition & $2.9 \times 10^{-1}$ \\
Produce - root uptake & $3.4 \times 10^{-7}$ \\
Produce - soil adhesion & $5.1 \times 10^{-6}$ \\
Grain - direct deposition & $2.9 \times 10^{-1}$ \\
Grain - root uptake & $6.8 \times 10^{-8}$ \\
Grain - soil adhesion & $1.2 \times 10^{-5}$ \\
Beverage & $1.0 \times 10^{-3}$ \\
\hline
\end{tabular}

The overall transfer factor is a measure of the concentration in a particular food via a specific food pathway that results from the deposition of radionuclides. If the expected concentration in food is small per unit deposition, the overall transfer factor will be small. Foods with higher expected concentrations have larger overall transfer factors. A comparison of the overall transfer factors for various foodstuffs and pathways shows which pathways result in the highest concentrations in food for a given deposition. 


\section{REFERENCES}

Environmental Protection Agency. Manual of protective action guides and protective actions for nuclear incidents. Washington, DC: EPA; EPA 400-R-92-001, 1992.

Food and Drug Administration. Accidental radioactive contamination of human food and animal feeds: recommendations for state and local agencies. Federal Register Vol. 47, No. 205, pp. 47073-47083: FDA; October 22, 1982.

Food and Drug Administration. Accidental contamination of human food and animal feeds: recommendations for state and local agencies. Rockville, MD: FDA; August 13, 1998a.

Food and Drug Administration. Guidance on accidental radioactive contamination of human food and animal feeds: recommendations for state and local agencies; availability. Federal Register Vol. 63, No. 156, pp. 43402-43403: FDA; August 13, 1998 b.

Hamby, D. M. Land and water use characteristics in the vicinity of the Savannah River Site. Aiken, SC; Westinghouse Savannah River Company; WSRC-RP-91-17; March 1991.

Hamby, D. M. Site-specific parameter values for the Nuclear Regulatory Commission's food pathway dose model. Health Phys. 62(2):136-143; 1992.

International Atomic Energy Agency. Handbook of parameter values for the prediction of radionuclide transfer in temperate environments. Vienna: IAEA; Technical Reports Series No. 364; 1994.

National Council on Radiation Protection and Measurements. Screening models for releases of radionuclides to atmosphere, surface water, and ground. Bethesda, MD: NCRP; NCRP Report No.123; 1996.

Nuclear Regulatory Commission. Calculation of annual doses to man from routine releases of reactor effluents for the purpose of evaluating compliance with $10 \mathrm{CFR}$ Part 50, Appendix I. Washington, DC: NRC; Regulatory Guide 1.109, Rev. 1; 1977a.

Shleien, B.; Chiacchierini, R. Background for protective action recommendations: accidental radioactive contamination of food and animal feeds. Rockville, MD: FDA; HHS Publication FDA 82-8196; 1982.

Till, J.; Meyer, H. Radiological assessment. Washington, DC: NRC; NUREG/CR3332/ORNL-5968; 1983. 